\title{
Scutellaria slametensis (Lamiaceae), a new species from Central Java, Indonesia
}

\author{
Sudarmono ${ }^{1}$ and B.J. Conn ${ }^{2}$
}

\author{
${ }^{1}$ Centre for Plant Conservation - Kebun Raya Bogor, Jl. Ir. H. Juanda No. 13, Bogor, Indonesia. \\ Email:s_darmono@yahoo.com \\ ${ }^{2}$ National Herbarium of New South Wales, Mrs Macquaries Road, Sydney NSW 2000, Australia. \\ Email: barry.conn@rbgsyd.nsw.gov.au
}

\begin{abstract}
The new species Scutellaria slametensis Sudarmono and B.J.Conn (Lamiaceae) from Gunung Slamet, Jawa Tengah, Indonesia is here described and illustrated. This species is morphologically similar to S. javanica, but can be distinguished by its pale blue corollas (cf. dark purple in S. javanica) and leaves that are longer and shortly attenuate at base (cf. broadly cuneate in S. javanica).
\end{abstract}

\section{Introduction}

The genus Scutellaria L. (Lamiaceae), a member of the subfamily Scutellarioideae (Paton in Harley et al. 2004), is subcosmopolitan, but poorly represented in moist tropical lowlands. The genus can be easily recognised by its distinctive calyx, with a protrusion, or 'cap' on the adaxial (upper) lobe. It consists of about 360 species (Li \& Hedge 1994; Paton 1990; Hsieh \& Huang 1995; Paton in Harley et al. 2004). The most recent account of the genus for the region was by Keng (1978) who recognised three species for Malesia, namely, S. discolor Colebr., S. indica L. and S. javanica Jungh. Based on leaf characters and density of glandular trichomes, he recognised two varieties within S. discolor (namely, var. discolor and var. cyrtopoda) and within S. javanica he recognised four varieties (namely, var. javanica, var. luzonica, var. russeliifolia and var. sumatrana). Recent plant collections from Gunung Slamet, Jawa Tengah, Indonesia, revealed an undescribed species of Scutellaria.

Terminology follows Conn (1984). Inflorescence terminology follows Briggs and Johnson (1979), as modified by Conn (1995). Since the herbarium of Kebun Raya Indonesia, Bogor has not been officially registered in Index Herbariorum (Holmgren and Holmgren (1998+), the acronym 'KRB', referring to 'Kebun Raya Bogor', is used in this paper. 
Scutellaria slametensis Sudarmono and B.J.Conn sp. nov.

S. javanica Jungh. affinis sed foliis longioribus (plerumque 50-155 mm) ovatis vel anguste ovatis, lamina basi breve attenuata, corolla lavandulacea differt.

Holotype: Indonesia: Jawa Tengah: Gunung Slamet Post III, Baturraden climbing track, Purwokerto, Sudarmono MN18SLA and Sumanto, 29 May 2008, (BO1877916); isotypes: KRB, NSW805395.

Perennial herb, $0.4-1.5 \mathrm{~m}$ high. Stem erect, quadrangular, often with internodes laterally grooved, densely hairy (200-280 hairs $\left./ \mathrm{mm}^{2}\right)$, hairs eglandular, minute, $0.02-1 \mathrm{~mm}$ long, straight or slightly curved distally, patent to slightly antrorse or slightly retrorse (particularly on older branchlets); densely glandular (up to c. 160 glands $/ \mathrm{mm}^{2}$ ), more plentiful on younger growth, glands c. $0.02 \mathrm{~mm}$ diameter, sessile, yellow to red. Leaves decussate; petiole (10-)18-25 mm long; lamina ovate to narrowly ovate, (46-)50155(-186) $\mathrm{mm}$ long, 25-40(-45) $\mathrm{mm}$ wide, base shortly attenuate, margin bluntly and shallowly crenate (blunt teeth $5-8$, sometimes as many as 10 ), apex acuminate, chartaceous, moderately hairy (especially on venation of abaxial surface), hairs as for branchlets, sparsely glandular (c. 6 glands $/ \mathrm{mm}^{2}$ ), glands as for branchlets. Inflorescence botryoidal, densely floriferous, narrowly conical, becoming more cylindrical in fruit, 40-140 long, 18-130 mm diam.; flowers opposite, 2 per node; bracts sessile, ovate to narrowly ovate, (1.5-)2-4 mm long, 1-1.2 mm wide, base attenuate, margin entire, apex acuminate, enclosing buds then becoming deflexed in flower, persistent through flowering stage, moderately to densely hairy, hairs $0.1-0.15 \mathrm{~mm}$ long, antrorse, densely glandular; uniflorescence monadic; pedicel (3-) $4-5 \mathrm{~mm}$ long, held at $35^{\circ}-55^{\circ}$ to rachis; prophylls (subtending single flowers) linear or linear-ovate, 5-8 $\mathrm{mm}$ long. Calyx green; tube 1-2 mm long, outer surface moderately hairy and glandular (hairs and glands as for branchlets); scutellum semi-circular, spreading, 1-1.5(-2.2) $\mathrm{mm}$ long dilated to $3 \mathrm{~mm}$ long in fruit; lobes $0.7-1.5 \mathrm{~mm}$ long, abaxial lobe slightly longer than adaxial lobe, hairs up to $0.4 \mathrm{~mm}$ long, glands occasional, red. Corolla white basally, pale blue to sometimes pale purple distally, 11-18(-23) mm long; outer surface hairy and glandular; tube basally very narrow and parallel-sided for 3-5 $\mathrm{mm}$, then curving sharply upwards and remaining parallel-sided for 4-6 $\mathrm{mm}$ and then broadening distally for 5-7 $\mathrm{mm}$, abaxial outer surface densely hairy, more densely hairy towards adaxial outer surface, hairs up to $0.2 \mathrm{~mm}$ long, patent multicellular, glandular; inner surface densely hairy near base of style (distal to corolla 'elbow', hairs $0.5-1.5 \mathrm{~mm}$ long, patent or slightly antrorse, unicellular, non-glandular, apex rounded), sparsely to moderately hairy distally (hairs 1-2 mm long, antrorse, multicellular, non-glandular, apex tapering to subacute); abaxial (anterior) lobes almost circular to broadly ovate, 4-6 mm long, 4-6 mm wide, base slightly cordate, margin distally 2-lobed (sinus $0.5-1 \mathrm{~mm}$ long); lateral lobes broadly triangular to oblong, 4-4.5 mm long, c. $2 \mathrm{~mm}$ wide; adaxial (posterior) lobes boat-shaped, 5-7(-9) $\mathrm{mm}$ long, 3-4 mm wide, partially enclosing stamens. Stamens included to slightly exserted; adaxial (posterior) pair basally adnate to corolla for 10-14 mm, curved upwards sharply; abaxial (anterior) pair adnate for 6-8 $\mathrm{mm}$, curved upwards more gradually than adaxial stamens; filaments 8-9 mm long, glabrous, except for a few hairs basally; anthers versatile, c. $1 \mathrm{~mm}$ long, margin of locule stomium densely hairy (hairs $0.2-0.3 \mathrm{~mm}$ long). Disk $0.8-1 \mathrm{~mm}$ high, 1-1.3 mm diam., densely glandular (glands hemispherical, c. $0.1 \mathrm{~mm}$ diam.); gynophore $0.3-0.5 \mathrm{~mm}$ long; ovary $0.5-0.8 \mathrm{~mm}$ long, $0.8-1 \mathrm{~mm}$ diam., densely glandular (as for disk); style 20-23 mm long, glabrous; stigma $0.7-1 \mathrm{~mm}$ long. Fruiting calyx with tube 3-7 mm long, somewhat ventrally gibbous, lobes patent or sub-patent, becoming 


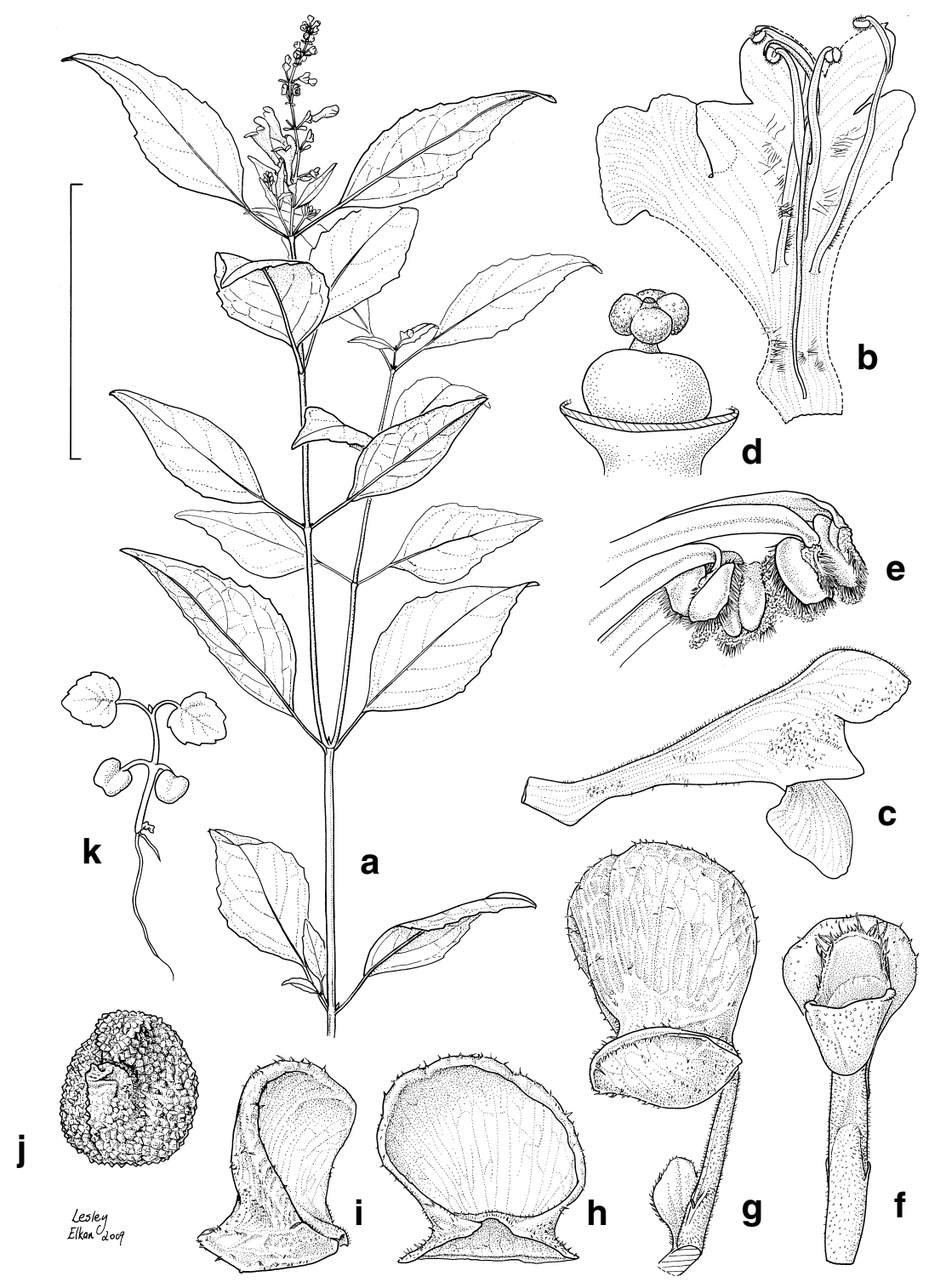

Fig. 1. Scutellaria slametensis $\mathbf{a}$, flowering branchlet; $\mathbf{b}$, open corolla showing androecium, style and stigma. Note: adaxial corolla lobe dissected and flattened to illustrate anthers; c, corolla (lateral view); d, detail of disk, gynophore and ovary, with style removed; e, detail of dehisced anthers and distal part of filaments, with corolla removed; $\mathbf{f}$, developing calyx (ventral view) with scutellum dorsal to adaxial calyx lobe, including prophylls on pedicel; $\mathbf{g}$, three-quarter view of mature calyx with lobes closed to protect developing seeds, scutellum strongly developed, with subtending leafy bract on pedicel; $\mathbf{h}$, dehisced adaxial calyx lobe and scutellum (dorsal view); i, dehisced adaxial calyx lobe and scutellum (lateral view); j, detail of seed (adaxial view); $\mathbf{k}$, seedling showing cotyledons and first true leaves, all from Sudarmono MN18SLA \& Sumanto (NSW). Scale bar: $\mathrm{a}=100 \mathrm{~mm}$; $\mathrm{b} \& \mathrm{c}=15 \mathrm{~mm}$; $\mathrm{d}$ e $\& \mathrm{j}=3 \mathrm{~mm} ; \mathrm{f}-\mathrm{i}=8 \mathrm{~mm} ; \mathrm{k}=30 \mathrm{~mm}$. 
thicker and more rigid with age, variable in length; scutellum (dehiscent with adaxial lobe) 4-5.5 mm long. Mericarps black or dark brown, broadly ellipsoid and slightly flattened, 1-1.5 mm long, darkly gland-dotted, not mucilaginous, lacking hooked tubercles. Fig. 1.

Distribution: only known from Gunung Slamet, Jawa Tengah, Indonesia.

Habitat: this species occurs in hill and submontane forests, in open shady areas along walking trail, in clay soils; at elevation of about 800-2400 m.

Other specimens examined: Indonesia: Jawa Tengah: Purbalingga Regency: Gunung Slamet: Hoover, Hunter, Wiriadinata and Girmansyah s.n., 14 March 2004 (BO1693907); Gowok forest, Hoover, Hunter, Wiriadinata and Girmansyah s.n., 14 March 2004 (BO1705600); Brebes Regency: Gunung Slamet Block Sakub, Kaligua, Pandansari village, Sudarmono MN03SLA and Sumanto, 27 May 2008 (BO1877957, KRB, NSW805394).

Conservation status: the conservation status of Scutellaria slametensis is Data Deficient but may prove to be Vulnerable because of its small number of populations and potentially few individuals.

Etymology: the epithet 'slametensis' refers to the name of the mountain (Gunung Slamet) from where the type material was collected.

Notes: Scutellaria slametensis is a short herb, 0.4-1.5 m high, similar in height to that of S. javanica (up to $1 \mathrm{~m}$ high), whereas $S$. discolor is shorter $(0.2-0.4 \mathrm{~m}$ high) and $S$. indica is larger (0.8-2.8 m high). In Scutellaria slametensis, flowering coincides with shoot expansion (pleonanthic sensu Hallé et al. 1978), typical of species of this genus and many other members of the Lamiaceae. The blastotelic inflorescence (sensu Briggs and Johnson 1979) is botryoidal consisting of monadic uniflorescences. Each node of the inflorescence of S. slametensis has a pair of flowers similar to S. indica and S. javanica, whereas S. discolor has 2-4 flowers per node. The surface of the mericarps of S. indica, $S$. javanica and S. slametensis all lack the acuminate tubercles, which are tipped by a whorl of hooks, that occur in S. discolor. Hooked tubercles also occur on the mericarp surface of S. austrotaiwanensis T.H.Hsieh \& T.C.Huang (1997) from Taiwan. Scutellaria slametensis has narrowly ovate leaves (similar to S. javanica), with margin bluntly crenate (cf. S. javanica crenate to remotely serrate) and both have bluish corollas. Scutellaria slametensis has pale blue corollas, whereas S. javanica mostly have dark blue to dark purple corollas. Scutellaria discolor and S. indica have more rounded leaves than the above species, with the margin crenate to coarsely crenate, and the corollas are mostly more darkly coloured, but, vary from pale blue to purple. This very distinctive species remains poorly known. Sterile material of S. slametensis is likely to be difficult to distinguish from Orthosiphon aristatus (Lamiaceae) because both habit and leaves are superficially similar.

Note: The pedicel is here regarded as the $\mathrm{a}_{1}$ axis plus anthopodium (refer Conn 1995).

\section{Key to Species in Indonesia}

1a. Distal flowers often in spiral-like clusters or almost so, $2-4$ flowers per node, radially spreading; inflorescences terminal; mericarps with acuminate tubercles terminating in a ring of hooks; bracts minute

S. discolor

1b. Flowers opposite, 2 per node, erect to suberect; inflorescence lateral or terminal; mericarps lacking hooked tubercles; bracts leaf-like 
2a. Herb up to $0.3(-0.4) \mathrm{m}$ high, usually prostrate, often unbranched; leaves mostly radical, broadly ovate to rounded or reniform, base truncate to cuneate, often cordate; flowers with pedicels almost patent to rachis S. indica

2b. Herb 0.4-1.5 m high, usually erect and branched; leaves spaced along stem, narrowly ovate, base shortly attenuate or broadly cuneate; flowers with pedicels obliquely erect to rachis

3a. Leaves with lamina 20-40(-60) mm long, 15-20 (-35) mm wide, base broadly cuneate, apex caudate-acuminate; corolla dark purple, $14-31 \mathrm{~mm}$ long S. javanica

3b. Leaves with lamina (46-)50-155(-186) mm long, 25-40(-45) mm wide, base shortly attenuate, apex acuminate; corolla distally pale blue to pale purple, $11-18(-23) \mathrm{mm}$ long

S. slametensis

\section{Acknowledgments}

Prof. H. Okada (Osaka City University, Japan) provided encouragement to examine this species. Prof. Mien A. Rifai (BO) provided helpful comments on the manuscript. We gratefully acknowledge the field assistance provided by Sumanto and Efendi Enta (both KRB), Sinung Nugroho (BKPH West Gunung Slamet) and Daryono in the Protected Forest of Gunung Slamet. We thank the directors of Kebun Raya Bogor (KRB), Herbarium Bogoriense (BO), and Pusat Penelitian Biologi-LIPI for permission to use facilities at their agencies. Generous support to visit Gunung Slamet Protected Forest was provided for one of us (S) as part of 'Project of Kiat-Kiat Memenangkan Proyek DIPA-LIPI'. Peter Wilson (NSW) kindly corrected the Latin diagnosis. We sincerely thank Lesley Elkan (NSW) for promptly providing the detailed illustration of this species.

\section{References}

Briggs BG \& Johnson LAS (1979) Evolution in the Myrtaceae - Evidence from inflorescence structure. Proceeding of the Linnean Society of New South Wales 102: 157-256.

Conn BJ (1984) A taxonomic revision of Prostanthera Labill. section Klanderia (F.v.Muell.) Benth. (Labiatae). Journal of the Adelaide Botanic Gardens 6: 207-348.

Conn BJ (1995) Description of inflorescence axes in the genus Logania R.Br. (Loganiaceae). Kew Bulletin 50: 777-783.

Hallé F, Oldeman RAA \& Tomlinson PB (1978) Tropical trees and forests. An architectural analysis. (Springer: Berlin)

Harley RM, Atkins S, Budantsey AL, Cantino PD, Conn BJ, Grayer R, Harley MM, Kok R de, Krestovskaja T, Morales R, Paton AJ, Ryding O \& Upson T (2004) Labiatae. Pp. 167-275 in Kubitzki K (ed.) The Families and Genera of Vascular Plants. In Kadereit JW (ed.) Volume VII Flowering Plants Dicotyledons. Lamiales (except Acanthaceae including Avicenniaceae). (Springer: Berlin)

Holmgren PK \& Holmgren NH (1998+) Index Herbariorum: A global directory of public herbaria and associated staff. New York Botanical Garden's Virtual Herbarium (http:// sweetgum.nybg.org/ih/)

Hsieh T-H \& Huang T-C (1995) Notes on the flora of Taiwan (20) - Scutellaria (Lamiaceae) in Taiwan. Taiwania 40: 35-56.

Hsieh T-H \& Huang T-C (1997) Notes on the flora of Taiwan (29) - Scutellaria austrotaiwanensis Hsieh \& Huang sp. nov. (Lamiaceae) from Taiwan. Taiwania 42: 109-116. 
Li X-W \& Hedge IC (1994) Scutellaria (Lamiaceae). Flora of China, 17: 75-103.

Keng H (1978) Labiatae. Pp 301-394 in Steenis CGGJ van (ed.) Flora Malesiana, series I, vol 8: Spermatophyta. (Noordhoff International Publishing: Leyden)

Paton AJ (1990) A global taxonomic investigation of Scutellaria (Labiatae). Kew Bulletin 45: 399-450.

Manuscript received 11 June 2009, accepted 06 November 2009 